Rua Prof. Marcos Waldemar de Freitas Reis Bloco O - Sala 507 - Campus do Gragoatá 24210-380 - Niterói - R veronica.secreto@ig.com.br
ASILO:

\section{DIREITO DE}

GENTES. ESCRAVOS

REFUGIADOS NO

IMPÉRIO ESPANHOL

\section{Maria Verónica Secreto**}

Universidade Federal Fluminense

\title{
Resumo
}

No século XVIII, os reis da Espanha estabeleceram, através de uma abundante legislação, uma política de asilo para os escravos que fugissem de outros domínios para os seus. Este artigo busca rastrear as origens dessa política e estabelecer sua relação com o princípio de "solo livre". Afirmamos que a legislação espanhola em matéria de escravidão influenciou todo o mundo atlântico e para além dele. Esta influência se deveu a que a Espanha tinha um conjunto importante de leis vivas sobre o tratamento dos escravos, resultado de um longo contato entre "povos" que vinha desde os tempos visigodos.

\section{Palavras-chave}

Asilo - escravos - Império espanhol.

* Este artigo é resultado da pesquisa desenvolvida durante o estágio pós-doutoral sênior, financiado com bolsa do Conselho Nacional de Desenvolvimento Científico e Tecnológico - CNPq.

${ }^{* *}$ Doutora pela Universidade Estadual de Campinas. Professora de História da América do Departamento de História do Instituto de Ciências Humanas e Filosofia. 


\title{
ASYLUM: RIGHTS OF PEOPLES. REFUGEE SLAVES IN HISPANIC EMPIRE
}

Contact

Rua Prof. Marcos Waldemar de Freitas Reis Bloco O - Sala 507 - Campus do Gragoatá 24210-380 - Niterói - R veronica.secreto@ig.com.br

\section{Maria Verónica Secreto}

Universidade Federal Fluminense

\begin{abstract}
In the eighteenth century, the Kings of Spain established by means of an abundant legislation, an asylum policy for the slaves who flee from other Kingdoms to the Spaniards territories. This research trace the origins of this policy and is possible to establish a relationship with the principle of "free soil". We affirm that the Spanish legislation on slavery have an strong influence across the Atlantic world and beyond. This influence was due to which Spain had an important set of living laws on the treatment of slaves and this is a result of a long contact between "people" coming from the Visigoth times.
\end{abstract}

\section{Keywords}

Asylum - slaves - Hispanic Empire. 
Desde los pueblos vecinos un aluvión de gentes de todas clases, sin distinción de esclavos o libres, ansiosos de novedad, acudieron a refugiarse allí. TITO LIVIO, Ab Urbe Condita.

\section{Introdução}

No final do século XVIII e principalmente durante o século XIX, o mundo atlântico conheceu o uso do conceito de "solo livre" na luta de escravos e abolicionistas. O Império espanhol tinha usado um instrumento semelhante para "libertar" escravos procedentes de outros territórios coloniais. Entre 1733 e 1789, os reis da Espanha legislaram outorgando refúgio ou asilo a escravos que escapavam de possessões hereges, inimigas ou que buscavam evadir-se de castigos excessivos. Isto que se tornou uma "política" e respondeu a conjunturas diferentes, bebia numa longa tradição escravista peninsular que, desde os tempos visigodos, vinha elaborando e reelaborando formas de sujeição e de afrouxamento das relações servis. A Reconquista foi a experiência que colocou em contato espanhóis e muçulmanos, europeus e africanos. A expansão atlântica possibilitou alargar as fronteiras das relações com os "outros". No século XVIII, o poder real espanhol disputou com o papado o governo dos homens, conseguindo circunscrever o asilo eclesiástico na medida em que alargava o asilo real, que se bem se substanciava num solo, não o tinha como princípio de direito. Predominava ainda a ideia de excepcionalidade. Apesar do princípio de asilo ou refúgio, como foi denominado na normativa espanhola desde o século XVII, não ser idêntico ao de solo livre de escravidão, que se configuraria como princípio de direito internacional no final do século XVIII, guarda alguns elementos que o configuraram e o antecipam.

Este artigo busca rastrear as origens da política espanhola de asilo aos escravos procedentes de outros territórios e, nesta busca, salienta a importância da legislação espanhola sobre escravidão em todo o mundo atlântico. Esta importância se deveu a que a Espanha tinha um conjunto importante de leis vivas que sancionavam o tratamento dos escravos. O direito castelhano reconhecia a lei de Toro, o ordenamento de Alcalá de Henares, os foros municipais, o Fuero Real de Alfonso X e as Siete Partidas. 


\section{O ordenamento espanhol do século XVIII}

Em1750, Fernando VI promulgou uma real cédula em que estabeleceu a liberdade dos negros e negras escravizados em outros domínios que chegassem aos seus. Disse:

Desde ahora en adelante para siempre queden libres todos los negros esclavos de ambos sexos que de colonias inglesas y holandesas de la América se refugiasen, ya sea en tiempo de paz como de guerra, a mis Dominios para abrazar nuestra Santa Fe Católica, y que no se moleste o notifique a negro o negra alguna que con este fin se huyesen en [sic] poder de sus dueños, pues con el hecho de llegar a mis dominios han de quedar libres, sin permitir que con pretexto algún se vuelvan a vender o reducir a la esclavitud. ${ }^{1}$

Com esta real cédula, Fernando VI buscava consolidar algumas resoluções que já tinha tomado antes. O teor da mesma seria reiterado numa real cédula de Carlos III em 1773, republicada por seu filho Carlos IV em 1789, ano significativo em matéria de legislação sobre escravos para a América espanhola.

Quando a real cédula de 1750 foi recebida em Filipinas, seu governador e a Real Audiência notificaram ao rei sua publicitação. Na notificação de 1752, o governador e capitão geral de Filipinas reiterava o texto da real cédula, incluindo seus antecedentes de 1733 e 1740, embora houvesse outros do século XVII. Informava também que a proclama (bando) emitida a partir da ordem real tinha sido, como de costume, apregoada na cidade de Manila tanto extramuros como intramuros para que ninguém pudesse argumentar ignorância. É interessante descrever brevemente o ritual seguido nessa ocasião. Começou às três da tarde da sexta-feira, 6 de setembro de 1752, fixando as duas folhas da lei nos lugares públicos habituais, quando também o pregoeiro, acompanhado pelo notário, quatro soldados e outras pessoas anunciou o conteúdo da lei pelas ruas de Manila. A este ato assistiram várias pessoas de diferentes qualidades. Concluiu-se dita publicação aproximadamente às seis da tarde. ${ }^{2}$ A forma de dar a conhecer esta real cédula, como outras, mostra como a política de asilo não era só uma questão entre "gabinetes", mas buscava atingir a população em geral, a qual deveria entender que, se bem a escravidão era legal, não era possível reduzir à escravidão os fugitivos dos domínios ingleses e holandeses.

\footnotetext{
1 MURO OREJÓN, Antonio (ed.). Cedulario americano del siglo XVIII. Tomo II. Madri: CSIC, 1969. (Colección de Disposiciones legales Indianas)

2 Archivo General de Indias, Esclavos refugiados 1753. AGI, 158, nº 340.
} 
Em 1773, a real cédula, dentro da tradição casuística, expressava o que tinha motivado a norma. O governador de Trinidad, em carta datada de junho de 1771 e em outra de maio de 1772, havia notificado o arribo de uma canoa com sete "negros" (não diz escravos) provenientes da ilha de Tabaco, distante 6 ou 7 léguas, aparecendo posteriormente outro tanto de refugiados proveniente de Esquivo. Informava el-rei que, em ambos os casos, o governador respondeu aos reclamos dos donos dos escravos dizendo que estava consultando o rei e seu Conselho das Índias e, entretanto, distribuiu os negros entre vizinhos com capacidade para dar de comer e vestir. Depois de consultar o Conselho das Índias e seu fiscal, el-rei diz:

he resuelto no entregueis los referidos negros á los que los reclaman como sus señores y dueños, pues no lo son según el derecho de las gentes desde que llegaron á territorio mio, y que hagais entender á todos los negros fugitivos, no solo la libertad que gozan con el hecho de su llegada á mis dominios, sino también la suma clemencia con que me digno admitirlos bajo mi real protección y amparo, exhortándolos á que en recompensa de tan inestimable beneficio y favor procuren portarse como fieles y agradecidos vasallos, y se ocupen como corresponde en los obrajes y tierras de esta ciudad, colocándolos vos á este fin separados y divididos, para que puedan mantenerse en las casas de los hacendados, á quienes prevendreis cuiden de su buena educación, $y$ vos estareis á la mira de que no los maltraten ni molesten, pues los han de servir como mercenarios, ${ }^{3}$ y no como esclavos, $y$ me dareis cuenta con testimonio de haberlo ejecutado. ${ }^{4}$

O documento é datado em El Pardo, em 20 de fevereiro de 1773.

Qual era esse direito de gentes a que se refere o documento? Desde o século XVI, o pensamento espanhol vinha reelaborando a teoria do direito de gentes de tradição romana, chegando à conclusão bastante genérica de que a condição humana outorgava direitos e que estes direitos pertenciam aos povos ou grupos humanos. Assim, os índios das Américas, como indicou Bartolomé de las Casas, tinham direito a não abraçar pela força a religião cristã. Como diz Dussel, a política moderna, e dentro desta o direito internacional, se origina da reflexão sobre a abertura do mundo europeu ao Atlântico. Por este motivo, os precursores da modernidade foram os portugueses

\footnotetext{
3 Segundo o Diccionario de autoridades de 1734, mercenário é "El trabajador o jornalero, [iv. 550] que por su estipendio y jornal trabaja en el campo. Latín. Mercenarius. Operarius. FONSEC. Vid. de Christ. tom. Parab. 24. Si fueres siervo, teme el azote: si mercenario, procura no perder el jornal: $y$ si hijo, trahe delante de los ojos el gusto y reverencia de tu padre. M. AGRED. tom. 3. num. 702. El trabajador y mercenario, acrecientan las fuerzas y el conato, quando llega la tarde, y no se acaba la tarea". Diccionario de la lengua castellana en que se explica el verdadero sentido de las voces, su naturaleza y calidad. Tomo IV. Real Academia Española, 1734.

${ }^{4}$ MURO OREJÓN, Antonio (ed.). Cedulario americano del siglo XVIII. Tomo III. Madri: CSIC, 1977. (Colección de Disposiciones legales Indianas, desde 1760 a 1780)
} 
e espanhóis, sobretudo estes últimos. A questão do outro, da legitimidade da conquista e da dominação esteve presente na escola chamada Segunda Escolástica ou Escola de Salamanca. ${ }^{5}$ Esta ideia do direito de gentes constitui-se, como alguns juristas reconhecem, num meio termo entre o direito natural - imutável e comum a todos os seres humanos - e o direito positivo - variável de lugar a lugar e histórico. ${ }^{6}$ Um representa a essência mesma das coisas, o outro é representado na opinião, na doxa. No meio termo entre imutabilidade e variedade, encontramos o direito das gentes: positivo, mas comum a todos os seres humanos. A escravidão, como já entendia o direito medieval - as Sete Partidas, por exemplo - era contrária ao direito natural e, por extensão, ao direito de gentes. Teólogos e juristas, não obstante, reconheciam algumas causas que podiam levar à escravidão. Entre os mais contrários à escravidão são citados dois capuchinos, Francisco José de Jaca e Epifanio Moirans que, depois de muita prédica, foram apresados (1682) e depois conduzidos a Europa de onde não poderiam mais retornar a América para predicar. Mas, segundo José Andres-Gallego, sua prédica não foi em vão. No ano seguinte, Carlos II promulgou uma real cédula que lembrava sobre o bom trato que deveriam receber os escravos, ademais de reforçar o direito a pleitear a mudança de senhor em caso de mau trato. ${ }^{7}$

Mencionamos que, em 20 de fevereiro de 1773, o rei Carlos IV reeditava a medida de amparar os escravos fugidos; também publicava outra real cédula sobre matéria diferente, embora relacionada, que tinha assinado poucos dias antes. Esta tratava do asilo nos termos medievais, ou melhor, em novos termos ainda com ressaibos medievais. ${ }^{8}$ Nesta real cédula, o rei mandava reduzir a quantidade de asilos eclesiásticos e mandava que isto fosse comunicado a seu conselho, aos presidentes e ouvidores e às audiências em todos os seus reinos, incluindo as Índias. O argumento temporal (já que parte do conflito entre Império e papado) era que a multiplicidade de asilos em todas as igrejas, cemitérios, campos santos, casas dos bispos, monastérios etc. permitia que muitos réus conseguissem a impunidade facilmente prejudicando a segurança pública. Ficava claro que o rei queria tomar em suas

\footnotetext{
DUSSEL, Enrique. Origen de la filosofía política moderna: Las Casas, Vitoria y Suárez (15141617). Caribbean Studies, vol. 33, no 2, jul-dez 2005, p. 35-80.

${ }^{6}$ Cf. MACEDO, Paulo Emílio Vauthier Borges de. A genealogia da noção de direito internacional. Revista da Faculdade de Direito da UERJ, vol. 1, nº 18, 2010.

7 ANDRÉS-GALLEGO, José. La esclavitud en la América española. Madri: Ediciones Encuentro, 2005.

${ }^{8}$ BACARDÍ Y JANER, Alejandro de. Nuevo Colon: ó sea Tratado del derecho militar de España y sus Indias. Madri: Establecimento Tipográfico de N. Ramirez, 1857.
} 
mãos e nas de seus administradores a justiça e que havia uma clara disputa por jurisdições. É claro também que o domínio espanhol era, por assim dizer, um domínio territorial imperfeito. Isto é, dentro do domínio real das Américas, por exemplo, admite-se que há corporações que também exercem o poder (ou um poder) jurisdicionalmente: as comunidades indígenas, os cabildos de índios, a Igreja, o patriarcado etc. O Estado espanhol não é territorial no sentido que seriam os estados nacionais modernos, mas pessoal. ${ }^{9}$

\section{Os tipos de asilo no século XVIII}

O direito espanhol reconhecia dois tipos de asilo: o que era realizado nas igrejas e o realizado em país estrangeiro. ${ }^{10} \mathrm{O}$ primeiro tipo de asilo tinha suscitado uma série de negociações entre os reis espanhóis e os papas. Durante o papado de Clemente XIV, as negociações do ministro de Carlos III em Roma conseguiram que o papa ordenasse, baseando-se na longa jurisprudência eclesiástica, que, a partir daquela data, 12 de setembro de 1772, a imunidade que outorgavam as igrejas a quem se refugiasse nelas depois de ter cometido um crime fosse reduzida, diminuindo-se o número de igrejas "protetoras". O papa salientava que esta diminuição do número de lugares santos nos domínios do rei da Espanha que outorgavam imunidade em nada alterava a sacralidade e respeito que devia ser guardado nesses locais nem diminuía a autoridade da Igreja.

\footnotetext{
9 Não cabe aqui discutir a natureza do Estado espanhol, basta destacar que, nos últimos anos, houve uma extensa discussão a respeito. Ver: CARDIM, Pedro; HERZOG, Tamar; RUIZ IBÁÑEZ, José Javier; SABATINI, Gaetano (ed.). Polycentric Monarchies. How did early modern Spain and Portugal achieve and maintain a global hegemony? Eastbourne: Sussex Academic Press, 2012; ELLIOT, John. Imperios del mundo atlántico. España y Gran Bretaña en América (1492-1830). Madri: Taurus, 2006. Estas abordagens que consideram as monarquias ibéricas e os impérios correspondentes como carentes de uma arbitragem central são contestadas por uma historiografia que não reconhece nelas originalidade alguma. "En el siglo XX los historiadores españoles usaban dos tipos de explicación de la Historia nacional en la Edad Moderna, la unitaria, que establecía que desde la Edad Media hubo una tendencia natural hacia la unificación institucional, política y social de España y su Imperio creando un espacio nacional integrado y la confederal que explicaba al pasado en términos de constitución de estados asociados en un fin común (primero la Reconquista, después el Imperio), que se asemejaban al Imperio Británico, por constituir una comunidad de estados, una Commonwealth, donde primaba la diversidad. La primera visión era el enfoque ortodoxo que el régimen del general Franco suministraba al sistema escolar, la segunda respondía a la interpretación de los nacionalismos periféricos". RIVERO RODRIGUEZ, Manuel. La recontrucción de la Monarquía hispánica: la nueva relación con los reinos (1648-1680). Revista Escuela de Historia, vol. 12, nº 1, Salta, jun 2013. ${ }^{10}$ BACARDÍ Y JANER, Alejandro de, op. cit.
} 
Sobre o "asilo" que outorgavam os outros países, o direito reconhecia que "o poder de uma nação não se estende para além dos limites da mesma", pelo qual, para castigar um criminoso que tivesse fugido para outra nação, era necessária sua extradição. Por esta razão, a Espanha assinou, durante os séculos XVIII e XIX, tratados de extradição com diferentes países como França, Inglaterra e Portugal. ${ }^{11}$

Mas nenhuma dessas duas formas se ajustam àquilo que, nas Américas, começou a ser mais ou menos frequente no século XVIII: o asilo outorgado aos escravos fugidos de outras possessões coloniais, sobretudo aos que fugissem de possessões "hereges" (protestantes), tinha o caráter de asilo religioso (não eclesiástico) pelo qual o rei de Espanha como rei católico assumia a proteção dos que buscassem o catolicismo em detrimento do protestantismo. Desta forma, o rei de Espanha disputava com a Igreja a questão da jurisdição, reduzindo os espaços eclesiásticos e dos vizinhos protestantes, impondo o que entendia como verdadeiro sentido da colonização e evangelização.

Em 1735, a companhia inglesa que provia de escravos as possessões espanholas desembarcou um carregamento de escravos provenientes do Congo no porto de Cartagena de Índias. Os escravos traziam marcada uma cruz no peito o que provocou certa "impressão" nos colonos espanhóis. Este caso despertou dúvidas no governador que escreveu ao rei pedindo instruções. O governador entendia que cristãos não podiam ser escravizados. Manuel Lucena Salmoral, ao analisar este caso, salienta o caráter original e tortuoso do parecer do fiscal - o rei consultava, nestes casos vindos da América, o seu Conselho de Índias e os fiscais. ${ }^{12}$ Naquela oportunidade, o fiscal retomou alguns dos princípios da escravidão hispana, como o fato de que cristãos não podem ser escravos de infiéis nem hereges. Portanto, o fiscal recomendava que estes escravos chegados em tão peculiares condições não deveriam ser devolvidos aos ingleses (hereges), mas, como qualquer outro cristão "resgatado" das mãos de hereges ou infiéis, deveriam devolver o "resgate" a quem os resgatou. Assim, o preço pago pela compra dos escravos se transformou em valor do resgate e os resgatados em devedores de seus senhores/resgatadores. ${ }^{13}$ Apesar da real cédula de 23 de outubro de 1736 ordenar a perma-

\footnotetext{
${ }^{11}$ Ibidem.

${ }^{12}$ LUCENA SALMORAL, Manuel. Los congoleños que traían marcada una cruz. Biblioteca Virtual Luis Ángel Arango. Disponível em: http://www.banrepcultural.org/blaavirtual/historia/lucena/ cristiaes/cristiaes1.htm. Acesso em: 10/01/2014.

${ }^{13}$ A reconquista de Granada (1492) não colocou ponto final na escravidão mediterrânea. Ela continuou por mais de três séculos de ambos os lados do Mediterrâneo. Desta experiência em
} 
nência dos escravos, agora como "servos resgatados" nas mãos de seus compradores, o rei alertava sobre o problema aberto e a necessidade da consulta a uma junta de teólogos, já que a South Sea Company, não podendo vender daí em diante os escravos cristianizados ao príncipe católico, os venderia a hereges, o que evidentemente não solucionava o problema, mas o agravava. O caso era bastante alarmante porque muitos dos escravos tinham instrução religiosa e muitos eram cristãos desde a infância. Segundo as leis espanholas, lembrava o rei, cristão não podia ser escravo de outro, nem se podia escravizar quem nascera livre. ${ }^{14}$

As Sete Partidas eram bastante claras a respeito dessa questão. A quarta Partida, título 21, lei 8 estabelecia que:

Judío ni moro ni hereje ni otro ninguno que no sea de nuestra ley puede tener cristiano por siervo; y cualquiera de ellos que contra esto hiciese, teniendo a sabiendas cristiano por siervo, debe morir por ello, $y$ perder todo cuanto que hubiere y ser del rey. Otrosí decimos que cualquiera de estos sobredichos que hubiere siervo que no fuese de nuestra ley, si aquel siervo se tornara cristiano, que se hace por ello libre luego que se hace bautizar y recibe nuestra fe, $y$ no está obligado a dar por sí ninguna cosa a aquel cuyo era antes que se tornase cristiano. ${ }^{15}$

O caso da South Sea Company colocava toda esta jurisprudência em debate. O fato de que os escravos fossem batizados antes de sair da África ou ao chegar à América não era o problema nem novidade, embora seja formulado assim pelo governador de Cartagena de Índias. O problema era que estes fossem comercializados por hereges. Desde 1713, a Inglaterra gozava do exclusivismo comercial de escravos nos territórios espanhóis. O chamado asiento inglés, obtido pela Inglaterra na paz de Utrecht depois da guerra de sucessão da Coroa espanhola, permitia a este país introduzir escravos provenientes da África na América e, junto com isto, ganhar a possibilidade de

\footnotetext{
que o "resgate" permitia a recuperação do cristão (também havia troca de escravos cristãos por muçulmanos), a Espanha toma a ideia para suas Índias. "El rescate de los esclavos, es decir la concesión de la libertad a través del pago de un precio convenido, se realiza tanto por personas privadas como por instituciones de diferente naturaleza (preferentemente de carácter religiosa pero también civil), con modalidad diversa según los países y los momentos históricos. A nivel general el problema de la redención de cautivos se inserta como un aspecto importante en las relaciones entre la cristiandad y el Islam, Europa y el norte de África durante los siglos XVI al XIX". BUCCIANTI, Cinzia. El rescate de cautivos en África. A propósito de las redenciones de la Orden de la Merced en Argel y Túnez durante los años 1723-1725. IH, 17, 1997, p. 61-78.

${ }^{14}$ Cédulas de Luis I (1724), cédulas de Felipe V (1724-1746). Cedulario americano del siglo XVIII, p. 191-192.

15 ALFONSO X EL SABIO. Las siete Partidas. Valladolid: Maxtor, 2010, p. 417.
} 
comercializar com a América tanto de forma legal, a partir do navio de permiso, como da forma mais cobiçada ainda, através do contrabando. ${ }^{16}$

Este caso de 1736, cuja discussão e resultados se estenderam até 1738, constitui um dos antecedentes da "política de asilo" que começou a ser mais utilizada a partir de 1750. Falamos em "política" pela insistência com que os reis espanhóis se referiram a este tema em diferentes reais cédulas e reais ordens emitidas, principalmente entre 1740 e $1800 .{ }^{17}$ Depois de uma real cédula de 1740 dirigida ao governador de Havana para pôr em liberdade alguns escravos procedentes da Jamaica, outras reais cédulas corroboraram esta política. Em 1750, ordena-se a liberdade dos escravos das colônias inglesas e holandesas que fugissem para o vice-reino de Nova Espanha para converter-se à religião católica. A mesma é reiterada em 1753. Em 1764, outra real cédula dirigida ao governador de Santo Domingo inova a respeito dos motivos da liberdade. Neste caso, tratava-se de escravos fugidos das possessões francesas, portanto, não poderia ser arguida a causa religiosa para sua não restituição. $\mathrm{O}$ argumento utilizado foi a rigorosidade com que eram tratados e a sujeição em que eram mantidos. Como antecedente "legitimador" acrescentava a real cédula que, nas vezes anteriores em que tinham sido restituídos os escravos a seus proprietários franceses, ainda que com a recomendação de não serem castigados pela fuga, estes tinham recebido castigos, o que motivou o reclamo espanhol. A respeito dos escravos "fugitivos" que viviam no território espanhol sem "sujeição cristã nem política", a real cédula acrescia que deviam ser atraídos por meios suaves para serem reduzidos a "población y vida cristiana, política y sociable", prometendo-lhes, se fosse necessário, o indulto em nome do rei.

No mesmo ano, aparece outro argumento. Já não o da religião, nem o do tratamento rigoroso, mas o de "fugidos do inimigo". Tratava-se de escravos fugidos de colônias inglesas para Margarita. Apesar de, em 1763, ter sido assinado o tratado definitivo de paz entre os reis de Espanha e França por uma parte e o de Grã Bretanha por outra, o rei, consultado seu conselho, determinou que, sendo os escravos do inimigo na época que buscaram refúgio nos domínios dele, isso lhes devia servir para ganhar a liberdade. Em

\footnotetext{
${ }^{16}$ DONOSO ANES, Rafael. Un análisis sucinto del asiento de esclavos con Inglaterra (1713-1750) y el papel desempeñado por la contabilidad en su desarrollo. Anuario de Estudios Americanos, 64, 2, jul-dez 2007, p. 105-144. Para uma análise geral sobre o tráfico negreiro no Rio da Prata ver: STUDER, Elena F. S. La trata de negros en el Río de la Plata durante el siglo XVIII. Buenos Aires, Facultad de Filosofia y Letras, 1958.

${ }^{17}$ Embora haja antecedentes no século XVII para o território da Flórida.
} 
1769, ainda se insistiria na não restituição dos escravos fugidos das colônias francesas para Santo Domingo.

Em meio a esta série de reais cédulas e ordens que ratificavam a não devolução dos escravos fugidos, principalmente nos casos de tratar-se de escravos de possessões não católicas, sobressai um convênio assinado entre as coroas de Espanha e Dinamarca para a mútua restituição de escravos e desertores na ilha de Porto Rico e nas dinamarquesas de Santa Cruz, Santo Tomás e São João (St. Croix, St. Thomas e St. Jan), datado em 21 de julho de 1767. ${ }^{18} \mathrm{O}$ reclamante, isto é, o particular cujos escravos tivessem fugido, teria um ano para formalizar a demanda. Depois disto, perderia o direito à restituição. Mas o reclamante pagaria um real de prata por dia de manutenção (cálculo de vestimenta e alimentação) e 25 pesos fortes pelos gastos de sua apreensão. Também era conveniado que os escravos que passassem das possessões dinamarquesas para as espanholas e que antes de sua restituição houvessem adotado a religião católica poderiam manter esta religião quando restituídos, isto enquanto sua majestade dinamarquesa continuasse permitindo o livre exercício da religião católica. Dessa forma, ficava claro, neste convênio, que a questão religiosa era fundamental e o que permitia a restituição era o fato de que o rei da Dinamarca assentia com o exercício da religião católica, mantendo igrejas e padres em suas possessões. Segundo Luis M. Díaz Soler, o que ajudou o acordo entre as duas coroas foi a extinção da Companhia Dinamarquesa das Índias Ocidentais que propiciava o contrabando entre as possessões da Dinamarca e a Espanha, pelo que esta última considerava "ressarcidas" as perdas que aqueles pudessem ter com os escravos fugidos. ${ }^{19}$ Para Hall o cimarronaje nas ilhas dinamarquesas foi intenso. Constituiu-se num real problema para os plantadores. Enquanto houve densas florestas suficientes que asseguraram resguardo e recursos, os escravos buscaram estas para refugiar-se. Na medida em que o açúcar demandou desmatamento e a cobertura vegetal foi desaparecendo, a melhor possibilidade de fuga para os escravos foi para fora das três ilhas. ${ }^{20} \mathrm{O}$ cimarronaje marítimo foi cada vez mais significativo no século XVIII. Já em 1702, chegou-se

\footnotetext{
${ }^{18}$ ESPANHA. Tratados, convenios y declaraciones de paz y de comercio que han hecho con las potencias extranjeras los monarcas españoles de la casa de Borbon desde 1700 hasta el día. Madri: Imprenta de Alegria y Charlaín, 1843.

${ }^{19}$ DÍAZ SOLER, Luis. Historia de la esclavitud negra en Puerto Rico. San Juan de Puerto Rico: Universidad de Puerto Rico, 1965, p. 234.

${ }^{20}$ HALL, Neville A. T. Maritime Maroons: "Grand marronage" from the Danish West Indies. The William and Mary Quarterly, third series, vol. 42, n 4, out 1985, p. 476-498.
} 
a ordenar o corte de todas as árvores que pudessem ser utilizadas para a confecção de canoas. Reimert Haagensen (1721-1771), plantador e cronista, afirmou que, em 1750, as fugas eram frequentes e numerosas e que o objetivo procurado pelos escravos era a ilha de Porto Rico, pelo que muitas vezes sequestravam barcos obrigando a tripulação a levá-los até lá. ${ }^{21}$ Para Hall os tratados de 1742, 1765, 1767 e 1776 entre a Espanha e Dinamarca foram pouco eficientes. Os espanhóis, diz ele, não demostraram muito interesse na restituição dos escravos fugidos. ${ }^{22}$ Em grande medida, a pouca "simpatia" com as restituições se devia à política de mais longa data de asilo, ou refúgio, e à ressignificação que passou a ter a escravidão entre os países protestantes. ${ }^{23}$

Para Eugenio Petit Muñoz o asilo outorgado pela Coroa espanhola em diferentes momentos do século XVIII se inscreve dentro do asilo territorial, em contrapartida com o outro, o asilo eclesiástico. ${ }^{24}$ Embora o primeiro se substancia materialmente em um solo, não pode ser definido essencialmente por esta relação. As jurisdições do Antigo Regime não foram muito claras e muitas vezes geraram conflitos pelas suas definições. Deve-se lembrar ainda que muitas jurisdições eram exercidas sobre um mesmo território, como no caso do Estado e da Igreja. De qualquer maneira, o asilo outorgado por legislação real em 1733, 1740, 1750, 1773 e 1789 tinha elementos do asilo territorial que predominaria nos corpos legais nacionais do século XIX, embora também, e sobretudo, tivesse traços da ordem do Antigo Regime de um asilo pessoal, de imunidades pessoais. O asilo eclesiástico amparava todos, livres e escravos, mas não cabia ao escravo enquanto fugitivo da escravidão; só no caso de ter cometido algum outro crime além da fuga, da mesma forma que não cabia ao índio escapado da encomenda.. 25

\section{Asilo: antecedentes medievais}

Na longa gênese do direito de asilo podemos mencionar o direito romano e canônico. No caso da península Ibérica, também foi reconhecido pelos direitos municipais recolhidos nos fueros de cada cidade. Os fueros lo-

\footnotetext{
${ }^{21}$ Apud HALL, op. cit., p. 486.

${ }^{22}$ Ibidem, p. 486-487.

${ }^{23}$ Distante do asilo a escravos da Antiguidade greco-romana, cf. GRENOUILLEAU, Olivier Pétré. Asyle. Diccionnaire des esclavages. Larousse à Present, 2010, p. 113.

${ }^{24}$ PETIT MUÑOZ, Eugenio. La condición jurídica, social, económica y política de los negros durante el coloniaje en la Banda Oriental, 1948, p. 246.

${ }^{25}$ Recopilación de las leyes de los reinos de las Indias. Quinta edição: Madri: Boix Editor, 1841.
} 
cais tinham suas bases no direito consuetudinário romano e visigodo e suas recopilações tinham âmbito supramunicipal: Fuero de Aragão, de Navarra, dos Castelhanos, Fuero Juzgo etc.

Os direitos locais, muitas vezes guardados com zelo pelos moradores das cidades, garantiam certas liberdades. É o caso analisado por Peabody que faz a genealogia de uma tradição que os advogados e juristas dos séculos XVII e XVIII cristalizariam como sendo o princípio do "solo livre francês". Peabody analisa as autonomias municipais de Toulouse (entre os reinos de França e de Aragão). Região de muitas guerras e disputas jurisdicionais entre os séculos XII e XIV, Toulouse se diferencia de outras cidades do reino por ter delimitado uma área ao longo do rio Garonne, Salvetat, que garantia privilégios e imunidades a seus habitantes, especificamente proteção legal e militar. Este direito tinha sido outorgado por seu senhor, o conde Alphonse-Jourdain, no século XII. A partir de então também suas autoridades judiciais ampliaram funções, jurisdições e alçadas. Um emblemático caso de 1203 serve para refletir sobre a origem do mito do princípio- mais que sobre a origem do princípio -, já que, como Sue Peabody diz, aos olhos modernos, o solo livre de proteção de Toulouse parece muito diferente do princípio nacional de solo livre invocado séculos mais tarde pelos advogados franceses. ${ }^{26}$ Devemos pensar que para que o princípio viesse a ter o viés que teria era necessário o surgimento do Estado nacional com uma soberania territorial clara e definida e não uma superposição de direitos territoriais como era o da Toulouse medieval.

De qualquer forma, vale salientar as principais caraterísticas do caso de 1203. Toulouse estava localizada a 120 km de Rosellón (denominação espanhola de Roussillon) que, entre os séculos XII e XVII, pertenceu primeiro a Catalunha e, depois de unificadas as coroas de Castela e Aragão, a Espanha. Nas terras catalãs, como em outras partes da península, a escravidão era mais do que corriqueira ou, melhor dizendo, para utilizar um termo da época, a "servidão", era uma instituição bastante estendida. A condição servil se estabelecia através da guerra ou por meio da compra e transformava o servo em objeto de transações econômicas e patrimoniais. Lembra-nos José Antonio Piqueras sobre a origem da difusão do termo escravo para se referir ao servo objeto de compra-venda:

\footnotetext{
${ }^{26}$ PEABODY, Sue. An alternative genealogy of the origins of French free soil: medieval Toulouse. Slavery \& Abolition: A Journal of Slave and Post-Slave Studies, 32, 3, p. 341-362.
} 
Los muchos sometidos que llegaron al norte de Italia y Alemania en los siglos XII y XIII de la costa dálmata - sclavonia - comenzaron a ser conocidos con el nombre de sklavus (esclavo) de donde toman el nombre moderno para una condición ancestral que hasta entonces en latín era designado con la palabra servi. ${ }^{27}$

As denominações mais utilizadas em Roussillon nos séculos XIII, XIV e XV eram captivi, servi, sclavi e raramente forsani e sarraceni, demostrando esta longa lista de denominações a variedade de situações que podiam levar ao cativeiro. ${ }^{28}$ No ano de 1203, os senhores Arnaud e Anton Izarn, nobres da cidade de Verfeil, vizinha a Toulouse, reclamaram a devolução de seus servos Pierre e Guillaume, sustentando que estes lhes pertenciam pelos princípios de dominium, hominium e fidelitatum (domínio, homenagem e fidelidade); mas Pierre e Guillaume responderam que eles nunca tinham concedido nem consentido no dominium, hominium e fidelitatum com os irmãos Izarn. Os argumentos senhoriais tanto quanto a resposta dos supostos servos mostram como o consentimento era parte importante neste vínculo. Os juízes centraram sua pesquisa e buscaram as testemunhas capazes de provar a "cidadania" dos implicados. Pierre e Guillaume conseguiram provar serem de Toulouse, apesar de os irmãos Izarn alegarem que eles "iam e vinham" entre Toulouse e Verfeil, tentando minar, dessa forma, a proteção procurada pelos supostos escravos. Mas os juízes entenderam que Pierre e Guillaume eram de Toulouse e que os senhores Izarn não tinham direitos sobre eles. ${ }^{29}$

A origem deste princípio defendido no município de Toulouse devia sustentar-se na tradição dos "direitos locais" que as cidades vão adquirindo ao longo da Idade Média e nas tradições do direito espanhol que tanto influenciaram o sul da França. Sobretudo aquelas tradições que foram recolhidas como estatuto jurídico supramunicipal, como é o caso de Fuero Juzgo. O Fuero Juzgo estabelecia, dentro de um conjunto bastante extenso de leis sobre direitos e obrigações dos servos, que nenhum mercador estrangeiro poderia levar escravo do reino para fora deste..$^{30} \mathrm{O}$ Fuero Juzgo foi um conjunto de leis que vigorou na península Ibérica e na região transpirenaica (toda a área do reino visigodo) desde o século VII. Embora se trate de uma legislação da época visigoda, foi recopilado no século XIII. Suas fontes são o

\footnotetext{
${ }^{27}$ PIQUERAS, José Antonio. La esclavitud en las Españas: un lazo trasatlántico. Madri: Catarata, 2011, p. 30.

${ }^{28}$ BRUTAILS, Auguste. Étude sur l'esclavage en Roussillon du XIIIe au XVIIe siècle. Paris: Larose et Focel, 1886.

${ }^{29}$ Cf. PEABODY, Sue, op. cit.

${ }^{30}$ Leyes III e IV. El libro de los jueces o Fuero Juzgo. Editorial Maxtor, 1841, p. 403.
} 
direito romano, o canônico e códigos visigodos anteriores. É de destacar que quando falamos em região transpirenaica, estamos nos referindo a uma extensa região que vai do centro-oeste francês (região centro e região dos países do Loire) até o sul, incluída a Costa Azul. Assim, parece mais ou menos claro que a tradição tolosana (Toulouse/Tolosa) de "solo livre" bebe tanto no antecedente imediato da outorga de imunidade pelo conde Adolphe Jourdan como no princípio jurídico visigodo que proibia que mercadores estrangeiros levassem servos para fora do reino.

\section{Asilo, refúgio e solo livre}

Se bem seja dificílimo traçar os antecedentes do princípio de solo livre até porque, como dizemos, para que este se constitua como tal requereu-se uma soberania territorial claramente teorizada (embora de fato muitas vezes não demarcada) -, parece que a península Ibérica, com sua larga tradição em legislação sobre "realidades multiculturais", teve um papel fundamental no traçado dos lineamentos do que se constituiria, no final do século XVIII e início do XIX, em direitos e obrigações dos escravos. O Fuero Juzgo, o Fuero Viejo de Castilla, as Sete Partidas, ${ }^{31}$ as Leyes de Toro etc. constituíram um corpo mais ou menos sólido em matéria de escravidão para a península e, depois, para a América espanhola. Manuel Lucena Salmoral, com o objetivo de oferecer um panorama do aparato jurídico que acompanhou a instituição escravista nas Américas, selecionou grande número de documentos para compor seu livro. ${ }^{32}$ Salienta que, embora o direito servil se fundamente no Fuero Juzgo e nas Partidas de Alfonso X, o escravismo indiano logo teve caraterísticas próprias, considerando, na sua análise, o ordenamento gerado inclusive pelas autoridades locais: vice-reis, governadores, audiências, cabildos etc. A recopilação de leis das Índias, apesar de reconhecer a escravidão, trata pouco dela, dedicando-se sobretudo a questões vinculadas com o tráfico e introdução de escravos. Devemos lembrar que, nas mesmas Leis de Índias, advertia-se no início que, quando nessa recopilação não houvesse lei ex-

\footnotetext{
${ }^{31}$ A influência das Sete Partidas no dia-a-dia judicial na América espanhola já foi abordada em SECRETO, María Verónica. Justiça na desigualdade: ações de liberdade, papéis de venda e preço justo. Rio da Prata, 1776-1815. Afro-Ásia, v. 42, 2010, p. 27-62.

${ }^{32}$ LUCENA SALMORAL, Manuel. Leyes para esclavos. El ordenamiento jurídico sobre la condición, tratamiento, defensa y represión de los esclavos en las colonias de la América Española, 2000, op. cit.
} 
pressa a respeito de algum tema, se guardassem as leis do reino de Castela, conforme as leis de Toro e as de Alcalá de Henares:

El orden de prelación de las fuentes del derecho castellano aceptado por la ley de Toro citada, era el mismo establecido por el Ordenamiento de Alcalá de Henares, promulgado en tiempos de Alfonso XI; o sea: en primer término, las leyes del propio ordenamiento; a falta de precepto aplicable en el Ordenamiento, el Fuero Municipal vigente en la ciudad de que se tratare, a falta del Fuero Municipal, el Fuero Real de Alfonso X, y a falta de precepto aplicable en el Fuero Real, el Código de las Siete Partidas. ${ }^{33}$

A ordem de preferência se manteve ao longo da Idade Média, as novas fontes promulgadas se incorporavam ao primeiro lugar desta lista, como aconteceu com a Nueva Recopilación (1567) e a Novísima Recopilación (1805).

Na medida em que a Espanha reconquistou um território (entendemos aqui reconquista como "um processo de expansão militar dos reinos cristãos hispânicos à custa do Islã, que esteve revestido e impulsionado por uma ideologia militante baseada nos princípios de guerra santa e de guerra justa, e que ademais teve uma incidência decisiva na conformação de umas sociedades de fronteira), ${ }^{34}$ foi construindo e pondo em prática um conjunto de instituições que informaram a conquista da América. O conjunto de leis que regiam a vida de "povos misturados" foi moldando as formas de dominação. A legislação medieval é extensa a respeito dos direitos e obrigações de mouros e judeus como servos e senhores de servos. Fica claro em toda ela que a condição cristã do servo e a condição moura ou judia do senhor desobriga o primeiro, transformando-o em liberto. Isto podia acontecer ainda quando a conversão, via batismo, fosse recente.

Neste último caso, não se trata de um território livre, mas da condição de livre recorrente da conversão, que transforma o "outro" em um de nós. Em uma sociedade de fronteira, como a dos reinos cristãos do período da "reconquista", garantir alguns salvo-condutos era fundamental para manter a preponderância cristã e a mobilidade da fronteira e das pessoas. Como foi também na América.

Em 1693, o rei Carlos II tinha outorgado uma real cédula que ordenava a liberdade de todos os escravos que chegassem a Flórida provenientes das possessões britânicas. Este é um dos casos mais estudados. A península da Flórida, de difícil conquista pela Espanha, tinha-se constituído em destino

\footnotetext{
${ }^{33}$ CASTAÑÓN GONZÁLEZ, Guadalupe. Legislación negra (El Afrocaribe colonial). Revista del Cesla, Uniwersytet Warszawski, Polonia, $\mathrm{n}^{0}$ 7, 2005, p. 109-124.

${ }^{34}$ GARCÍA FITZ, Francisco. La Reconquista: un estado de la cuestión. Clio \& Crimen, nº 6, 2009, p. 142-215.
} 
de fugas escravas, tanto daqueles que buscavam a aliança com os índios para internar-se em seus territórios quase "impenetráveis"35 como dos que buscavam a fronteira espanhola para escapar do jugo da escravidão, "experimentando" outras relações entre os hispanos, como fora a possibilidade de somar-se às milícias negras alocadas na defesa do Circuncaribe. Os batalhões negros foram amplamente utilizados pelo Império espanhol para defesa de Havana, Puerto Rico, Cartagena e Santo Domingo. Parafraseando o que diz Landers - ao se referir às honrarias que a oficialidade espanhola recomendou para o pirata mulato, capitão Diego Martín -, os espanhóis eram capazes de um pragmatismo racial que levou inclusive a reconhecer que os homens livres de cor podiam ser honoráveis e valentes. ${ }^{36}$

Os especialistas em direito internacional falam em laicização do direito de asilo eclesiástico que se explica pelo processo de monopolização do poder público. Assim, do asilo eclesiástico se passaria ao asilo político com fundamento no princípio de territorialidade. A origem deste tipo de asilo, moderno, estaria nas guerras religiosas do século XVI. O Edito de Nantes de 1598, assinado pelo rei Henrique IV, permitiu que protestantes calvinistas pudessem praticar livremente seu culto na França. Este edito dispõe sobre o princípio de soberania territorial. A partir daí, trata-se de um refúgio territorial, não eclesiástico, outorgado por autoridade pública, não espiritual, embora, posteriormente, Luiz XIV limitasse este direito. Durante as perseguições iniciadas com a revogação do edito de Nantes, 300.000 pessoas deixaram a França buscando refúgio na Inglaterra, Holanda, Suíça e Berlim. Neste novo contexto, a Inglaterra ditou a Act for Naturalizing Protestants, criando outro dos marcos do asilo territorial ${ }^{37}$ e, talvez, outra das ramas do princípio de solo livre.

Mas é claro que essa passagem de uma forma de asilo a outra, para nós historiadores, não se dá com absoluta linearidade e, entre uma e outra forma,

\footnotetext{
${ }^{35}$ LANDERS, Jane. Black society in Spanish Florida. University of Illinois, 1999; MULROY, Kevin. Freedom in the border: The Seminole Maroons in Florida. The Indian territory. Coahuila and Texas. Texas: Tech University Press, 1993. LANDERS, Jane. Cimarrones africanos e indios en la frontera española con los Estados Unidos. El caso de los semínolas negros de la Florida. In: Resistencia y Manumisión. Javeriana, 2007. Para processos de etnogênese em outras fronteiras ver: GOMES, Flavio dos Santos. Los cimarrones y las mezclas étnicas en las fronteras de las Guayanas. Siglos XVII-XX. Procesos Históricos, vol. III, nº 16, 2009, p. 24-39.

${ }^{36}$ LANDERS, Jane. Movilidad de la diáspora y comunicación entre la población de origen africano en el Circuncaribe. In: VELÁZQUEZ, Maria Elisa (coord.). Debates históricos contemporáneos: africanos y afrodescendientes en México y Centroamérica. México: INA/UAM, 2011, p. 59-84. p. 68.

${ }^{37}$ CORNEJO, Alejandra Rosalba. El asilo jurídico. Análisis histórico y perspectivas a futuro. Tese, Universidad de las Américas, Puebla, México, 2005, p. 87.
} 
há uma série de continuidades e descontinuidades. Onde localizar o direito de refúgio a escravos fugidos de território herege ou inimigo outorgado por sucessivos reis espanhóis? Será que a tradição que percorreu as várias fronteiras do Império espanhol de norte a sul através do Atlântico e do Pacífico não teve nada a ver com o princípio de solo livre que difundiriam os abolicionistas desde o último quartel do século XVIII? Será que o pragmatismo espanhol que privilegiou a ocupação e manutenção de seus territórios antes da preservação das hierarquias de origem não teve por trás alguma ideia de direito para além do princípio de benevolência e soberania do príncipe?

A longa experiência da Reconquista, que significou a convivência com o "outro", inclusive na escravização do "outro", deixou um conjunto de direitos e costumes que implicaram em diferentes formas de sair da escravidão. Estas formas foram todas as que reconheciam o direito romano e outras, como a da impossibilidade de que o servo fosse comprado por mercador estrangeiro para ser tirado do reino. E ainda, práticas como as que permitiam que um sarraceno (escravo que não abandonara a religião muçulmana) pudesse ser resgatado por um mudéjar (muçulmano livre vivendo em territórios cristãos com direito a preservar sua religião). ${ }^{38}$ Como afirmam Casares e Barranco, foi na legislação medieval que as questões fundamentais sobre sujeição foram estabelecidas. ${ }^{39}$ Mas foi na América que elas ganharam nova vida e foram desafiadas por realidades diversas. O Caribe foi o cenário onde a imaginação de reis e autoridades espanholas foi mais amplamente testada. A Espanha teve que fazer frente às "pretensões" francesas, inglesas, holandesas e dinamarquesas. Foi das fronteiras com estes três últimos que o argumento de "escapado de domínio herege" foi ressignificado para permitir o ingresso dos escravos fugidos que buscavam refúgio, esperando que, em troca, se comportassem "como fieles y agradecidos vassalos". Talvez o que se buscava eram fiéis e agradecidos vassalos. Isto parece o mais seguro de se afirmar. Não somente enfraquecer o inimigo retirando-lhe homens, mas fortalecer os próprios territórios através da incorporação de homens gratos. Mas não somente.

\footnotetext{
${ }^{38}$ MARZAL PALACIOS, Francisco Javier. La esclavitud en Valencia durante la Baja Edad Media. (13751425). Tese, Universidad de Valencia, Espanha, 2006, p. 1147-1164.

${ }^{39}$ MARTÍN CASARES, Aurelia \& GARCÍA BARRANCO, Margarita. Legislation on free soil in nineteenth-century Spain: the case of the slave Rufino and its consequences (1858-1879). Slavery E Abolition: A Journal of Slave and Post-Slave Studies, 32, 3, 2011, p. 461-476.
} 
A política de asilo espanhol percorreu o império de norte ao sul: da Flórida a Colônia de Sacramento. ${ }^{40}$ A intensidade das fugas dependeu de questões circunstanciais. ${ }^{41}$ Durante as guerras coloniais, que foram muitas na segunda metade do século XVIII, os escravos se aproveitaram da conjuntura favorável para fugir de domínios portugueses, ingleses e franceses e pedir asilo sob o domínio espanhol.

Paralelamente ao direito de asilo, a Espanha tratava a devolução de escravos de acordo com tratados "binacionais" específicos, criando certa confusão sobre quais os casos em que se devia restituir os escravos. ${ }^{42}$ Mas as contradições não pararam por aí. Em 1791, outra real cédula de 24 de novembro autorizava a livre introdução de escravos negros nas ilhas do Caribe. Dos africanos que foram introduzidos como escravos em todas as possessões espanholas do Novo Mundo ao longo de quatro séculos, mais da metade desembarcaram em Cuba entre as décadas de 1790 e 1870. ${ }^{43}$ Em 1796, um novo regulamento para a captura de cimarrones evidenciou que já não se toleraria a existência de escravos fugidos enquanto a demanda por eles crescia. Se bem estas medidas podem parecer contraditórias: por um lado libertar os escravos procedentes de domínios hereges ou de senhores maus tratadores (franceses), por outro, incentivar o tráfico e capturar os cimarrones; no fundo trata-se de aumentar a quantidade de súditos escravos e livres num momento que o Império espanhol pensa a empresa americana como uma empresa de povoamento e de produção agrária.

A reiteração do princípio de asilo em 1789, ano em que Carlos IV também emitiu a real cédula sobre a educação, trato e ocupação dos escravos nos seus domínios de Índias e ilhas Filipinas, evidencia uma das preocupações dos reis espanhóis enquanto piedosos cristãos - não vamos avaliar aqui a sinceridade desta - com o bom trato dos escravos, argumento mais utilizado para não devolver os escravos fugidos de território francês, embora

\footnotetext{
${ }^{40}$ ACRUCHE, Hevelly Ferreira. Escravidão e liberdade em territórios coloniais: Portugal e Espanha na fronteira platina. Dissertação de mestrado, UFF, 2013.

${ }^{41}$ AIZPURÚA, Ramón. Esclavitud, navegación y fugas de esclavos en el Curazao del siglo XVIII. In: $A A V V$, Poder local, poder global en América Latina. Barcelona: Universitat Barcelona, 2008.

${ }^{42}$ GRINBERG, Keila. Fronteiras, escravidão e liberdade no sul da América. Rio de Janeiro: 7 Letras, 2013.

43 MARQUESE, Rafael. 1808 e o impacto do Brasil na construção do escravismo cubano. Revista USP, São Paulo, nº 79, set-nov 2008, p. 118-131.
} 
outro argumento vinha se consolidando e, de alguma forma, incorporandose ao direito de gentes: o de humanidade. ${ }^{44}$

\section{Conclusão}

Embora o princípio de asilo ou refúgio, como foi denominado na normativa espanhola desde o século XVII, não seja idêntico ao de solo livre de escravidão, ${ }^{45}$ que se configuraria como princípio de direito internacional no final do século XVIII, ${ }^{46}$ guarda alguns elementos que o configuraram e o antecipam. Pensar numa história atlântica, conectada ou global demanda uma dupla perspectiva, a sincrônica e a diacrônica. Do ponto de vista sincrônico, algumas práticas parecem inerentes à condição humana como as fugas e a formação de "comunidades". Quilombos, palenques, cumbes e mainels, como atos extremos no campo da política, ${ }^{47}$ povoam o território americano quase por completo. Mas as motivações para as fugas, as formas que as fugas tiveram, a construção social depois das fugas etc. foi particular a cada experiência. As estratégias da libertação também foram particulares e específicas. O expediente do asilo como forma de obtenção da liberdade teve, como tantos outros, mão dupla. Para os reis da Espanha significava a possibilidade de dar continuidade a guerra santa e a guerra justa tão caras à Reconquista; consolidar o poder real frente ao da Igreja; e obter súditos gratos e fieis. Para os escravos que buscavam os domínios espanhóis significava escapar daquilo conhecido, a escravidão, sem conhecer, em muitos casos, o mundo ao qual iam. ${ }^{48}$ Do ponto de vista diacrônico, vemos que uma série de instituições medievais informa e transforma-se na conquista de América. Mas também vemos as adaptações e apropriações intencionais que a jurisprudência, códigos e normas experimentam no Novo Mundo. A densidade temporal oferece a possibilidade de tecer genealogias mais ou menos prováveis, sem a certeza do DNA.

\footnotetext{
${ }^{44}$ MARQUESE, Rafael. Feitores do corpo, missionários da mente: senhores, letrados e o controle dos escravos nas Américas (1660-1860). São Paulo: Companhia das Letras, 2004, p. 89-92.

${ }^{45}$ Livre de escravidão porque, como vimos, o princípio de solo livre para a prática religiosa protestante pode ser considerado a primeira forma deste princípio territorial.

${ }^{46}$ A respeito ver o dossiê sobre solo livre organizado por PEABODY, Sue E GRINBERG, Keila. Slavery \& Abolition: A Journal of Slave and Post-Slave Studies, 32, 3, 2011.

${ }^{47}$ FLORENTINO, Manolo \& AMANTINO Marcia. Fugas, quilombos y fujões nas Américas (séculos XVI-XIX). Análise Social, 203, XLVII (2º), 2012, p. 237.

${ }^{48}$ Em alguns casos havia uma fluidez surpreendente entre fugitivos e "sociedade envolvente". Ver: GÓMES, Flavio dos Santos, op. cit.; FLORENTINO, Manolo \& AMANCIO, Márcia, op. cit. e AIZPURÚA, Ramon, op. cit.
} 
No asilo dos séculos XVII e XVIII não é a terra que outorga a liberdade, mas a proteção real consubstanciada num território. Mas apesar desta diferença não podemos deixar de salientar a influência desta prática e da legislação que a sustenta no mundo atlântico dos séculos XVIII e XIX.

\section{Referências bibliográficas}

ACRUCHE, Hevelly Ferreira. Escravidão e liberdade em territórios coloniais: Portugal e Espanha na fronteira platina. Dissertação de mestrado, UFF, 2013.

AIZPURÚA, Ramón. Esclavitud, navegación y fugas de esclavos en el Curazao del siglo XVIII. In: $A A V V$, Poder local, poder global en América Latina. Barcelona: Universitat Barcelona, 2008.

ALFONSO X EL SABIO. Las siete Partidas. Valladolid: Maxtor, 2010.

ANDRÉS-GALLEGO, José. La esclavitud en la América española. Madri: Ediciones Encuentro, 2005.

BACARDÍ Y JANER, Alejandro de. Nuevo Colon: ó sea Tratado del derecho militar de España y sus Indias. Madri: Establecimento Tipográfico de N. Ramirez, 1857.

BRUTAILS, Auguste. Étude sur l'esclavage en Roussillon du XIIIe au XVIIe siècle. Paris: Larose et Focel, 1886.

BUCCIANTI, Cinzia. El rescate de cautivos en África. A propósito de las redenciones de la Orden de la Merced en Argel y Túnez durante los años 1723-1725. IH, 17, 1997, p. 61-78.

CARDIM, Pedro; HERZOG, Tamar; RUIZ IBÁÑ̃Z, José Javier; SABATINI, Gaetano (ed.). Polycentric Monarchies. How did early modern Spain and Portugal achieve and maintain a global hegemony? Eastbourne: Sussex Academic Press, 2012.

CASTAÑÓN GONZÁLEZ, Guadalupe. Legislación negra (El Afrocaribe colonial). Revista del Cesla, Uniwersytet Warszawski, Polonia, nº 7, 2005, p. 109-124.

CHILE. Sesión del día 11 de octubre [1811]: Bando de libertad de vientres. Santiago: Imprenta Chilena, 1846. (Colección de las Leyes i Decretos del Gobierno desde 1810 hasta 1823)

CORNEJO, Alejandra Rosalba. El asilo jurídico. Análisis histórico y perspectivas a futuro. Tese, Universidad de las Américas, Puebla, México, 2005.

DÍAZ SOLER, Luis. Historia de la esclavitud negra en Puerto Rico. San Juan de Puerto Rico: Universidad de Puerto Rico, 1965.

DONOSO ANES, Rafael. Un análisis sucinto del asiento de esclavos con Inglaterra (1713-1750) y el papel desempeñado por la contabilidad en su desarrollo. Anuario de Estudios Americanos, 64, 2, jul-dez 2007, p. 105-144.

DUSSEL, Enrique. Origen de la filosofía política moderna: Las Casas, Vitoria y Suárez (1514-1617). Caribbean Studies, vol. 33, nº 2, jul-dez 2005, p. 35-80.

ELLIOT, John. Imperios del mundo atlántico. España y Gran Bretaña en América (1492-1830). Madri: Taurus, 2006.

ESPANHA. El libro de los Jueces o Fuero Juzgo. Editorial Maxtor, 1841. 
Tratados, convenios y declaraciones de paz y de comercio que han hecho con las potencias extranjeras los monarcas españoles de la casa de Borbon desde 1700 hasta el día. Madri: Imprenta de Alegria y Charlaín, 1843.

FLORENTINO, Manolo $\mathcal{E}$ AMANTINO Marcia. Fugas, quilombos y fujões nas Américas, (séculos XVI-XIX). Análise Social, 203, XLVII (2º), 2012, p. 236-267.

GARCÍA FITZ, Francisco. La Reconquista: un estado de la cuestión. Clio E Crimen, $\mathrm{n}^{\mathrm{0}}$ 6, 2009, p. 142-215.

GOMES, Flavio dos Santos. Los cimarrones y las mezclas étnicas en las fronteras de las Guayanas. Siglos XVII-XX. Procesos Históricos, vol. III, nº 16, 2009, p. 24-39.

GRENOUILLEAU, Olivier Pétré. Asyle. Diccionnaire des esclavages. Larousse à Present, 2010.

GRINBERG, Keila. Fronteiras, escravidão e liberdade no sul da América. Rio de Janeiro: 7 Letras, 2013.

HALL, Neville A. T. Maritime Maroons: "Grand Marronage" from the Danish West Indies. The William and Mary Quarterly. Third series, vol. 42, $\mathrm{n}^{\circ} 4$, out 1985, p. 476-498.

LANDERS, Jane. Black society in Spanish Florida. University of Illinois, 1999.

Cimarrones africanos e indios en la frontera española con los Estados Unidos. El caso de los semínolas negros de la Florida. In: Resistencia y Manumisión. Javeriana, 2007.

. Movilidad de la diáspora y comunicación entre la población de origen africano en el Circuncaribe. In: VELÁZQUEZ, Maria Elisa (coord.). Debates históricos contemporáneos: africanos y afrodescendientes en México y Centroamérica. México: INA/UAM, 2011, p. 59-84.

LUCENA SALMORAL, Manuel. Los congoleños que traían marcada una cruz. Biblioteca Virtual Luis Ángel Arango. Disponível em: http://www.banrepcultural. org/blaavirtual/historia/lucena/cristiaes/cristiaes1.htm. Acesso em: 10/01/2014.

. Leyes para esclavos. El ordenamiento jurídico sobre la condición, tratamiento, defensa y represión de los esclavos en las colonias de la América española. 2000.

MACEDO, Paulo Emílio Vauthier Borges de. A genealogia da noção de direito internacional. Revista da Faculdade de Direito, UERJ. (Separata)

MARQUESE, Rafael. 1808 e o impacto do Brasil na construção do escravismo cubano. Revista USP, São Paulo, nº 79, set-nov 2008, p. 118-131.

. Feitores do corpo, missionários da mente: senhores, letrados e o controle dos escravos nas Américas (1660-1860). São Paulo: Companhia das Letras, 2004, p. 89-92.

MARTÍN CASARES, Aurelia \& GARCÍA BARRANCO, Margarita. Legislation on free soil in nineteenth-century Spain: The case of the slave Rufino and its consequences (1858-1879). Slavery $\mathcal{E}$ Abolition: A Journal of Slave and Post-Slave Studies, 32, 3, 2011, p. 461-476.

MARZAL PALACIOS, Francisco Javier. La esclavitud en Valencia durante la Baja Edad Media (1375-1425). Tese, Universidad de Valencia, 2006.

MULROY, Kevin. Freedom in the border: The Seminole Maroons in Florida. The Indian territory. Coahuila and Texas. Texas: Tech University Press, 1993. 
MURO OREJÓN, Antonio (ed.). Cedulario americano del siglo XVIII. Tomo II. Madri: CSIC, 1969. (Colección de Disposiciones legales Indianas)

Cedulario americano del siglo XVIII. Tomo III. Madri: CSIC, 1977. (Colección de Disposiciones legales Indianas, desde 1760 a 1780)

PEABODY, Sue. An alternative genealogy of the origins of French free soil: medieval Toulouse. Slavery \& Abolition: A Journal of Slave and Post-Slave Studies, 32, 3, 2011, p. 341-362.

PEABODY, Sue $\mathcal{E}$ GRINBERG, Keila. Slavery $\mathcal{E}$ Abolition: A Journal of Slave and Post-Slave Studies, 32, 3, 2011.

PETIT MUÑOZ, Eugenio. La condición jurídica, social, económica y política de los negros durante el coloniaje en la Banda Oriental. 1948.

PIQUERAS, José Antonio. La esclavitud en las Españas: un lazo trasatlántico. Madri: Catarata, 2011.

PROVINCIAS UNIDAS DEL RIO DE LA PLATA. El Supremo Poder Executivo Provisorio de las Provincias Unidas del Rio de la Plata. 1813.

REAL ACADEMIA ESPAÑOLA. Diccionario de la lengua castellana en que se explica el verdadero sentido de las voces, su naturaleza y calidad. Tomo IV. Real Academia Española, 1734.

Recopilación de las leyes de los reinos de las Indias. Quinta edição. Madri: Boix Editor, 1841.

RIVERO RODRIGUEZ, Manuel. La recontrucción de la Monarquía hispánica: la nueva relación con los reinos (1648-1680). Revista Escuela de Historia, vol. 12, n 1, Salta, jun 2013.

SECRETO, María Verónica. Justiça na desigualdade: ações de liberdade, papéis de venda e preço justo. Rio da Prata, 1776-1815. Afro-Ásia, v. 42, 2010, p. 27-62. 